\title{
IGFBP3 wt Allele
}

National Cancer Institute

\section{Source}

National Cancer Institute. IGFBP3 wt Allele. NCI Thesaurus. Code C52282.

Human IGFBP3 wild-type allele is located within 7p13-p12 and is approximately $9 \mathrm{~kb}$ in length. This allele, which encodes insulin-like growth factor-binding protein 3 , plays a role in the regulation of insulin-like growth factor and in inhibition processes in the extravascular tissue compartment. 